\title{
Structure and pharmacological actions of
} phyllocaerulein, a caerulein-like nonapeptide: its occurrence in extracts of the skin of Phyllomedusa sauvagei and related Phyllomedusa species

\author{
A. ANASTASI, G. BERTACCINI, J. M. CEI, G. DE CARO, \\ V. ERSPAMER AND M. IMPICCIATORE
}

Institutes of Pharmacology, Universities of Rome and Parma, Farmitalia S.p.A. Laboratories for Basic Research, Milan, Italy, and Institute of Biology, National University of Cuyo, Mendoza, Argentina

1. The South American amphibian Phyllomedusa sauvagei contains in its skin large amounts of a polypeptide closely resembling caerulein in its pharmacological actions. This polypeptide, called phyllocaerulein, was obtained in a pure form, and upon acid hydrolysis, enzymic digestion and end-group determination experiments it proved to be a nonapeptide of the following composition

Pyr-Glu-Tyr $\left(\mathrm{SO}_{3} \mathrm{H}\right)$-Thr-Gly-Trp-Met-Asp-Phe- $\mathrm{NH}_{2}$

It may be seen that caerulein and phyllocaerulein have in common the $\mathrm{C}$ terminal heptapeptide and the $\mathrm{N}$-terminal pyroglutamyl residue.

2. Phyllocaerulein is indistinguishable from caerulein even in parallel bioassay. However, the former polypeptide seems to be somewhat more potent than the latter on all the preparations tested.

3. In different batches of Phyllomedusa sauvagei skin the phyllocaerulein content ranged between 150 and $600 \mu \mathrm{g} / \mathrm{g}$ of fresh tissue.

Phyllocaerulein or similar polypeptides occur also in the skin of several other Phyllomedusa species, among which are Phyll. burmeisteri, Phyll. dachnicolor, Phyll, helenae, Phyll. annae, Phyll. callidryas and Phyll. bicolor.

4. The qualitative identification and quantitative estimation of caerulein-like polypeptides in crude skin extracts may be complicated by the concomitant occurrence of other active polypeptides. These, however, are poorly effective on some test preparations which seem to respond selectively to caerulein.

5. Like that of caerulein, the biological significance of phyllocaerulein is completely obscure.

It was suggested in a preceding paper (Anastasi, Erspamer \& Endean, 1968), on the basis of results of bioassay, that the skin of some amphibians from Central and South America belonging to the genus Phyllomedusa might contain caerulein or caerulein-like polypeptides. 
The present communication gives an account of the isolation, structure and pharmacological properties of the caerulein-like polypeptide occurring in the skin of Phyllomedusa sauvagei from north-western regions of Argentina. For the new polypeptide, a nonapeptide closely resembling caerulein both from a biological and chemical point of view, the name phyllocaerulein is proposed.

$$
\begin{aligned}
& \text { Pyr-Gln-Asp-Tyr( } \left.\mathrm{SO}_{3} \mathrm{H}\right) \text {-Thr-Gly-Trp-Met-Asp-Phe- } \mathrm{NH}_{2} \\
& \text { Caerulein } \\
& \text { Pyr-Glu-Tyr( } \left.\mathrm{SO}_{3} \mathrm{H}\right) \text {-Thr-Gly-Trp-Met-Asp-Phe-NH }{ }_{2} \\
& \text { Phyllocaerulein }
\end{aligned}
$$

This paper also describes the occurrence of phyllocaerulein or related peptides in the skin of other Phyllomedusa species.

A complete description of methods used in the isolation of phyllocaerulein as well as in the determination of amino-acid composition and amino-acid sequence of the polypeptide may be found in a preceding paper dealing with the isolation and the amino acid sequence of caerulein (Anastasi, Erspamer \& Endean, 1968 ; Anastasi, 1969).

\section{Methods}

\section{Amphibian material}

The following Phyllomedusa material was used in this study.

1. 113 specimens of Phyllomedusa sauvagei captured in January 1963. The total weight of the fresh skins was $268 \mathrm{~g}$ and the average weight of one skin was $2.36 \mathrm{~g}$.

2. Forty-one specimens of Phyllomedusa sauvagei captured in December 1963 and January 1964. The total weight of the fresh skins was $107 \cdot 4 \mathrm{~g}$ and the average weight of one skin was $2 \cdot 62 \mathrm{~g}$.

3. Fifty-two specimens of Phyllomedusa sauvagei captured in January 1965. The total weight of the dried skins was $37.25 \mathrm{~g}$ and the average weight of one skin was $0.72 \mathrm{~g}$.

4. Seventy specimens of Phyllomedusa sauvagei captured in January 1966. The total weight of the fresh skins was $170 \mathrm{~g}$ and the average weight of one skin was $2 \cdot 43 \mathrm{~g}$.

5. Fifty-six specimens of Phyllomedusa sauvagei captured in February 1966. The total weight of the fresh skins was $130 \mathrm{~g}$ and the average weight of one skin was $2 \cdot 32 \mathrm{~g}$.

6. 144 specimens of Phyllomedusa sauvagei captured in December 1966 and January 1967. The total weight of the fresh skins was $261.2 \mathrm{~g}$ and the average weight of one skin was $1 \cdot 81 \mathrm{~g}$.

7. 369 specimens of Phyllomedusa sauvagei captured in December 1967 and January 1968. The total weight of the fresh skins was $887.2 \mathrm{~g}$ and the average weight of one skin was $2.4 \mathrm{~g}$. This batch of skins constituted pool 1968, and represented, together with batch 6 , the starting material used for preparation of pure natural phyllocaerulein.

All specimens of Phyllomedusa sauvagei were adult and were captured in regions near Tucuman, Argentina.

8. 2,397 adult specimens of Phyllomedusa rohdei captured near Rio de Janeiro in the period December 1965 to April 1966. The dried skins weighed together $293.3 \mathrm{~g}$ and the average weight of one skin was $0.12 \mathrm{~g}$. 
9. 460 adult specimens of Phyllomedusa hypochondrialis captured near Resistencia, Chaco, Argentina, in May 1964. The total weight of the fresh skins was $90.8 \mathrm{~g}$ and the average weight of one skin was $0.2 \mathrm{~g}$.

10. Three adult specimens of Phyllomedusa callidryas captured in Panama in January 1964. The total weight of the dried skins was $0.3 \mathrm{~g}$.

11. Four adult specimens of Phyllomedusa helenae captured in Costa Rica in August 1964. The total weight of the dried skins was $1.03 \mathrm{~g}$.

12. Twelve adult specimens of Phyllomedusa annae captured in Costa Rica in May 1962. The total weight of the dried skins was $3.35 \mathrm{~g}$ and the average weight of one skin was $0.28 \mathrm{~g}$.

13. Seven adult specimens of Phyllomedusa annae captured in Costa Rica in July 1964. The total weight of the fresh skins was $6.5 \mathrm{~g}$ and the average weight of one skin was $0.93 \mathrm{~g}$.

14. Four adult specimens of Phyllomedusa dachnicolor captured near Morelos, Mexico, in September 1964. The total weight of the dried skins was $3.8 \mathrm{~g}$.

15. Eight adult specimens of Phyllomedusa bicolor captured near Obidos, Parà, Brazil in January 1967. The total weight of the fresh skins was $91.8 \mathrm{~g}$ and the average weight of one skin was $11.5 \mathrm{~g}$.

16. Nine adult specimens of Phyllomedusa burmeisteri captured near Rio de Janeiro in May 1963. The dried skins were divided into two parts which were then extracted separately : parotoid glands (total weight $0.84 \mathrm{~g}$ ) and remaining skin (total weight $3 \mathrm{~g}$ ). The average weight of a complete skin was $0.43 \mathrm{~g}$.

17. Forty specimens of Phyllomedusa burmeisteri captured at the same place in January-February 1966 . The dried skins weighed together $40 \mathrm{~g}$ and the average weight of one skin was $0.38 \mathrm{~g}$.

18. 101 adult specimens of Phyllomedusa burmeisteri captured at the same place in December 1966. The total weight of the fresh skins was $166 \mathrm{~g}$ and the average weight of a skin was $1.6 \mathrm{~g}$.

Extracts of fresh skins were prepared on the spot. The skins were removed from the animals immediately after killing them and extracted twice with five parts $(w / v)$ of methanol. The skins destined to be dried were carefully spread out and dried in the shade. Soon after their arrival in Italy, by air mail, they were minced with scissors and then immersed in twenty times their weight of $80 \%$ methanol. The liquid was then decanted after a week, and the skins were treated for another week with a further fifteen to twenty parts of the solvent. The methanol extracts were mixed and filtered. Kept in dark bottles and refrigerated $\left(+4^{\circ} \mathrm{C}\right)$, they can be stored for months and years without appreciable loss of activity.

\section{Bioassay}

Biological assay of caerulein-like polypeptides was carried out, in parallel, on the following preparations: dog blood pressure, guinea-pig gall bladder in vivo, dog jejunal loop in vivo, denervated gastric pouch of the dog, perfused stomach preparation of the rat and the dog pancreas. All these test objects were prepared exactly as described in previous papers (Bertaccini, De Caro, Endean, Erspamer \& Impicciatore, 1968a, 1968b, 1969 ; Bertaccini, Endean, Erspamer \& Impicciatore, 1968). 
Caerulein and phyllocaerulein elicited a fall in dog blood pressure, caused contraction of the guinea-pig gall bladder and the dog jejunal loop, stimulated acid secretion in the denervated gastric pouch of the dog and in the perfused stomach preparation of the rat and, finally, stimulated the flow of pancreatic juice in the dog. Only the acid output of the stomach preparations was measured, and only the volume of pancreatic juice.

Physalaemin-like polypeptides were detected and eventually estimated quantitatively using the isolated rabbit colon and, subordinately, the dog blood pressure ; bradykinin-like polypeptides were identified using the isolated rat uterus and subordinately the isolated guinea-pig ileum and the dog blood pressure ; finally, the "antidiuretic" activity of the skin extracts was assayed in hydrated rats. Details of methods are given elsewhere (Erspamer \& Falconieri Erspamer, 1962 ; Anastasi, Bertaccini \& Erspamer, 1966).

\section{Paper chromatography}

Caerulein-like polypeptides could be visualized on paper chromatograms run with the $n$-butanol:acetic acid:water mixture (40:10:60) if the NNCD reagent or the p-dimethylaminobenzaldehyde reagent were used as locating reagents. With these reagents caerulein gave orange and violet-blue spots respectively, because of the presence in the caerulein molecule of the tryptophanyl residue. Threshold amounts of peptides were of the order of $10-20 \mu \mathrm{g}$.

The above reagents were suitable also for the detection of other tryptophanecontaining peptides, generally lacking biological activity on our test objects, which were present in large amounts in skin extracts of some Phyllomedusa species (for example, Phyllomedusa rohdei, Phyllomedusa hypochondrialis).

Biogenic aromatic amines were visualized on paper chromatograms by the same reagents and by Pauly's reagent.

\section{Reagents and drugs}

Pure natural phyllocaerulein was obtained by the procedure described in this paper. Natural caerulein, synthetic phyllocaerulein and synthetic physalaemin were prepared at the Farmitalia Laboratories for Basic Research, Milan. Synthetic bradykinin was a gift of Messrs. Sandoz, Basle.

Other drugs were obtained from the following sources: crystalline chymotrypsin from Fluka A.G. Buchs, Switzerland, and from Princeton Laboratory Products, Princeton, N.J., U.S.A. ; crystallized and lyophilized type VII subtilisin from the Sigma Chemical Co., St. Louis, Missouri, U.S.A. ; crystalline carboxypeptidase from Fluka A.G., Buchs, Switzerland; leucine aminopeptidase from Nutritional Biochemicals Corporation, Cleveland, Ohio, U.S.A.; DEAE-Sephadex A-25 from Pharmacia, Uppsala, Sweden ; finally NNCD reagent (2-chloro-4-nitrobenzenediazoniumnaphthalene-2-sulphonate) from Hopkins \& Williams Ltd., Chadwell Heath, Essex.

\section{Results}

\section{Isolation of phyllocaerulein}

The starting material for the isolation of phyllocaerulein was the $80 \%$ methanol extract of the dried skins of Phyllomedusa sauvagei constituting batches 6 and 7 . 
In a typical experiment an amount of extract corresponding to $50 \mathrm{~g}$ of tissue was reduced to a small volume by evaporation under reduced pressure and submitted to a short counter-current distribution between petroleum ether and aqueous $80 \%$ ethanol in order to remove fat-like substances. The active material collected in the aqueous fractions was further purified by counter-current distribution with the system $n$-butanol:ethanol:acetic acid:water $(80: 16: 16: 128)$ using 200 transfers. In this step most of the contaminating amino-acids and amines and most of the pigments were removed.

The pooled active fractions were then chromatographed on a small column of DEAE-Sephadex A-25 in the $\mathrm{OH}^{-}$form eluted with ammonium carbonate solutions of increasing concentrations from $0.05 \mathrm{M}$ to $1 \mathrm{M}$. Phyllocaerulein emerged when the concentration of effluent reached $1 \mathrm{M}$ while all the contaminants still present were removed in the preceding fractions. The sample was finally desalted by passage through a small column of Amberlite CG-50 in the $\mathrm{H}^{+}$form eluted with water. Phyllocaerulein emerged unretarded in the first fractions while the ammonium ion was retained on the resin.

The peptide purified as above gave a single spot on paper chromatography and electrophoresis, thus proving to be unitary and pure. The spot was negative to ninhydrin, positive to the reagents for tyrosine, methionine and tryptophane and it was associated with biological activity. On high voltage electrophoresis phyllocaerulein migrated anodically in acidic and neutral mediums at a rate slightly higher than that of caerulein.

\section{Pharmacological actions of phyllocaerulein}

Phyllocaerulein displayed a spectrum of pharmacological effects identical with that displayed by caerulein (cf. Bertaccini et al., 1968a, 1968b, 1969 ; Bertaccini et al., 1968). In fact, it elicited a relatively prolonged pressure fall in the dog, produced a powerful contraction of the gall bladder of the guinea-pig in vivo and of the ileum of the dog in vivo, stimulated gastric acid secretion in the dog and the rat, and finally potently stimulated pancreatic secretion in the dog.

Table 1 shows the results of a parallel bioassay of natural caerulein, natural phyllocaerulein and synthetic phyllocaerulein on the above six test objects. The activity of caerulein was always considered equal to 100 and that of the phyllocaeruleins was expressed as a percentage.

TABLE 1. Results of parallel bioassay of natural caerulein, natural phyllocaerulein and synthetic phyllocaerulein on six test objects

Relative activity $(\%)$ of

\begin{tabular}{|c|c|c|}
\hline \multirow{2}{*}{$\begin{array}{c}\text { Caerulein } \\
\text { Natural }\end{array}$} & \multicolumn{2}{|c|}{ Phyllocaerulein } \\
\hline & Natural & Synthetic \\
\hline $\begin{array}{l}100 \\
100 \\
100\end{array}$ & $\begin{array}{l}140-150 \\
110-135 \\
120-140\end{array}$ & $\begin{array}{l}150-160 \\
120-150 \\
130-150\end{array}$ \\
\hline $\begin{array}{l}100 \\
100 \\
100\end{array}$ & $\begin{array}{l}120-150 \\
130-160 \\
110-140\end{array}$ & $\begin{array}{l}110-150 \\
150-160 \\
120-150\end{array}$ \\
\hline
\end{tabular}

Dog blood pressure

Guinea-pig gall bladder in situ

Dog jejunal loop in situ

Gastric acid secretion

dog denervated fundic pouch

perfused rat stomach preparation

Pancreatic secretion of the dog

$\begin{array}{cc}\text { Caerulein } \\ \text { Natural } \\ & 100 \\ & 100 \\ & 100 \\ & 100 \\ & 100 \\ \text { ation } & 100\end{array}$

The activity of caerulein was always considered equal to 100; that of the phyllocaeruleins was expressed as a percentage. 
It may be seen from the tabulated data that phyllocaerulein was more potent than caerulein on all examined test objects. Differences were of the order of 10 to $60 \%$ on a weight basis. Table 1 also shows that synthetic phyllocaerulein was identical with natural phyllocaerulein.

As expected, phyllocaerulein and caerulein presented a similar behaviour not only towards enzymic digestion, but also towards treatment with diazonium salts in acid medium, treatment with hydrogen peroxide and hydrolysis by glacial acetic acid (cf. De Caro, Endean, Erspamer \& Roseghini, 1968).

It may be concluded that at present it is very difficult to distinguish phyllocaerulein from caerulein by bioassay or other methods. Thus, in the presence of caerulein-like activities in crude tissue extracts it is prudent to speak simply of caerulein-like peptides.

\section{Phyllocaerulein content in different batches of Phyllomedusa sauvagei skin}

Table 2 shows the phyllocaerulein content in the seven examined batches of Phyllomedusa sauvagei skin, as determined by bioassay on the usual test systems.

Phyllocaerulein was not the only active polypeptide occurring in the skin of Phyllomedusa sauvagei. In addition to varying amounts $(15-100 \mu \mathrm{g} / \mathrm{g})$ of a bradykinin-like polypeptide, it contained another polypeptide which conspicuously retarded elimination of a water load in rats. The study of these accompanying polypeptides is in progress, and until it is accomplished we must accept the possibility that they may interfere in some way with the effects of phyllocaerulein. Some discrepancies in the results of the parallel assay of our crude extracts might be explained by these interferences.

It is probable that drying the skins caused a more or less important inactivation of phyllocaerulein. Batch 3, the only one consisting of dried skins, had a rather low content of the polypeptide, in spite of the fact that $1 \mathrm{~g}$ of dried skin corresponded to $3-4 \mathrm{~g}$ of fresh skin.

Occurrence of caerulein-like polypeptides in the skin of other Phyllomedusa species

Table 3 presents the occurrence and content of caerulein-like polypeptides in the skin of eight Phyllomedusa species other than Phyllomedusa sauvagei, as determined on the guinea-pig gall biadder and the perfused rat stomach preparation. It further

TABLE 2. Content of phyllocaerulein in different batches of Phyllomedusa sauvagei skin

Content of phyllocaerulein $(\mu \mathrm{g} / \mathrm{g})$ in skin determined by

$\begin{array}{cccccc}\text { Batch } & \begin{array}{c}\text { Dog blood } \\ \text { pressure }\end{array} & \begin{array}{c}\text { Guinea-pig } \\ \text { gall bladder }\end{array} & \begin{array}{l}\text { Gastric acid secretion } \\ \text { Dog }\end{array} & \begin{array}{c}\text { Dog pancreatic } \\ \text { secretion }\end{array} \\ 1 & 175 & 190 & 200 & 215 & 160 \\ 2 & 300 & 205 & 210 & 215 & -150 \\ 3 & 280 & 145 & 165 & 145 & 400 \\ 4 & 475 & 625 & 410 & 200 \\ 5 & 285 & 270 & 300 & 315 & 385 \\ 6 & 600 & 500 & 330 & 330 & 410 \\ 7 & 570 & 525 & 615 & 500 & \end{array}$

Contents are expressed as $\mu \mathrm{g}$ of phyllocaerulein per $\mathrm{g}$ of fresh skin, except for batch 3 , which refers to dried skins. - , Not tested. 
presents data on occurrence and content of physalaemin-like polypeptides, as determined on the atropinized large intestine of the rabbit, of bradykinin-like polypeptides, as determined on the atropinized rat uterus, and finally on the " antidiuretic" polypeptide, as determined on the diuresis of hydrated rats. Batch 7 of Phyllomedusa sauvagei skin (Pool 1968) is included in the table for comparison.

The following results emerge from the tabulated data:

(a) As much as six of the eight examined Phyllomedusa species contained in their skin appreciable amounts of caerulein-like peptides. (b) In Phyllomedusa burmeisteri the parotoid glands were several times richer in peptides, including the caerulein-like peptide, than the remaining skin. (c) Caerulein-like peptides were always accompanied by varying, sometimes considerable, amounts of other active polypeptides, already described in other papers (Erspamer, Bertaccini \& Cei, 1962 ; Bertaccini, Cei \& Erspamer, 1965 ; Anastasi et al., 1966).

The polypeptide spectrum is qualitatively and quantitatively different in each Phyllomedusa species. As a consequence, the polypeptide mixture of each species must be studied separately and identification of the single components of the mixture presupposes their isolation in a pure form and elucidation of their amino acid composition and sequence.

If, as stated previously, bioassay is inadequate to distinguish from each other pure caerulein and pure phyllocaerulein, distinction is even more difficult in the case of crude skin extracts containing other active peptides. With some test

TABLE 3. Occurrence and contents of active peptides in the skin of nine Phyllomedusa species, as determined on five test objects

\begin{tabular}{|c|c|c|c|c|c|}
\hline & \multicolumn{2}{|c|}{ Caerulein-like peptides } & \multirow{2}{*}{$\begin{array}{c}\text { Physalaemin- } \\
\text { like } \\
\text { peptides } \\
\text { Rabbit } \\
\text { large } \\
\text { intestine }\end{array}$} & \multirow{2}{*}{$\begin{array}{c}\text { Bradykinin- } \\
\text { like } \\
\text { peptides } \\
\text { Rat } \\
\text { uterus }\end{array}$} & \multirow{2}{*}{$\begin{array}{c}\text { "Anti- } \\
\text { diuretic" } \\
\text { peptide } \\
\text { Hydrated } \\
\text { rats }\end{array}$} \\
\hline & $\begin{array}{c}\text { Guinea-pig } \\
\text { gall } \\
\text { bladder }\end{array}$ & $\begin{array}{c}\text { Rat } \\
\text { stomach } \\
\text { preparation }\end{array}$ & & & \\
\hline $\begin{array}{l}\text { Phyllomedusa sauvagei } \\
\text { (Argentina) Pool } 1968 \mathrm{~F}\end{array}$ & 525 & 500 & $2 \cdot 5-3$ & $20-30$ & $(100)$ \\
\hline $\begin{array}{l}\text { Phyllomedusa rohdei } \\
\text { (Brazil) Pool } 1966 \mathrm{D} \\
\text { Phvllomedusa hypochondrialis }\end{array}$ & $<1$ & $<1$ & $13-15$ & $700-800$ & $(<5)$ \\
\hline $\begin{array}{l}\text { (Argentina) May } 1964 \mathrm{~F} \\
\text { Phyllomedusa burmeisteri } \\
\text { (Brazil) }\end{array}$ & $<1$ & $<1$ & $2-4$ & - & $(<5)$ \\
\hline 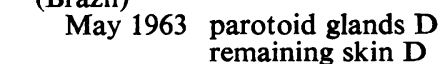 & $\begin{array}{r}600 \\
70\end{array}$ & 二 & 二 & $\begin{array}{r}200 \\
40\end{array}$ & $\begin{array}{r}(300) \\
(30)\end{array}$ \\
\hline $\begin{array}{l}\text { Jan.-Feb. } 1966 \text { D } \\
\text { December } 1966 \text { F }\end{array}$ & $\begin{array}{r}50-130 \\
350-450\end{array}$ & $\begin{array}{r}40-200 \\
150-300\end{array}$ & $\begin{array}{l}12-14 \\
10-12\end{array}$ & $\begin{array}{l}80-100 \\
50-70\end{array}$ & $\begin{array}{c}(70-80) \\
(110-120)\end{array}$ \\
\hline $\begin{array}{l}\text { Phyllomedusa callidryas } \\
\text { (Panama) January 1964 D }\end{array}$ & $5-7$ & - & $330-350$ & - & (10) \\
\hline $\begin{array}{l}\text { Phyllomedusa helenae } \\
\text { (Costa Rica) August } 1964 \\
\text { Phyllomedusa annae }\end{array}$ & $300-330$ & - & 300 & 10 & $(5-10)$ \\
\hline (Costa Rica) May 1962 D & $\begin{array}{l}650 \\
100\end{array}$ & $\overline{100}$ & $\begin{array}{l}100 \\
3 \cdot 5\end{array}$ & $\begin{array}{l}0 \cdot 5 \\
0 \cdot 15\end{array}$ & $\begin{array}{l}(<5) \\
(<5)\end{array}$ \\
\hline $\begin{array}{l}\text { Phyllomedusa dachnicolor } \\
\text { (Mexico) September 1964 D } \\
\text { Phyllomedusa bicolor } \\
\text { (Brazil) January } 1967 \mathrm{~F}\end{array}$ & $\begin{array}{c}130 \\
650-700\end{array}$ & $\begin{array}{l}120-150 \\
400-500\end{array}$ & $\begin{array}{l}450-500 \\
500-3000\end{array}$ & $50-80$ & (100) \\
\hline
\end{tabular}

Contents are expressed in $\mu \mathrm{g}$ of caerulein (for caerulein-like peptides), physalaemin (for physalaeminlike peptides) and bradykinin (for bradykinin-like peptides) per $g$ fresh (F) or dried (D) skin. -, Not tested. Values in parentheses refer to the antidiuretic principle and indicate the percent "antidiuretic" activity in comparison to the activity of Phyllomedusa sauvagei skin, arbitrarily considered equal to 100. 
objects (for example, dog blood pressure) even the qualitative demonstration of caerulein-like peptides may be impossible. However, if the preparations are employed on which caerulein displays its most potent and specific actions (for example, guinea-pig gall bladder, dog pancreas, rat stomach preparation) not only the qualitative demonstration of caerulein-like peptides will be easy, but also their reasonably accurate quantitative estimation. Of course, it is always necessary that the ratio of accompanying polypeptides to caerulein-like peptides is not exceedingly high.

\section{Occurrence in the skin of Phyllomedusa, of biogenic amines and of tryptophane-containing peptides other than caerulein}

Skin extracts of some species of Phyllomedusa, especially of Phyllomedusa rohdei and of Phyllomedusa hypochondrialis, contained several peptides, other than caerulein, which gave, on paper chromatograms, the reactions characteristic of tryptophane. Generally they were present in considerable amounts and were inactive on our biological test preparations.

For Phyllomedusa rohdei the study of these peptides is in progress, and elucidation of the amino-acid composition and sequence of two small peptides is near to being accomplished.

Indolealkylamines, imidazolealkylamines and phenylalkylamines were apparently lacking in the Phyllomedusa skin. The only exception was represented by Phyllomedusa rohdei, which contained in its skin 5-10 $\mu \mathrm{g}$ of bufotenine per g dry tissue.

\section{Discussion}

Phyllomedusa sauvagei, an amphibian living in the north western regions of Argentina, contains in its skin a nonapeptide, phyllocaerulein, closely related to the decapeptide caerulein occurring in the skin of the Australian hylid frog Hyla caerulea.

The concentration of phyllocaerulein in the cutaneous tissue is similar to that found for caerulein. Although phyllocaerulein is somewhat more potent than caerulein in all the biological preparations tested, the two polypeptides are virtually indistinguishable from each other by parallel bioassay.

Extracts of the skin of several other Phyllomedusa species collected in South and Central America present more or less pronounced caerulein-like activities. It is possible that these are due in every instance to authentic phyllocaerulein, but it is evident that definite conclusions on this point can only be reached after isolation and analysis of the peptides occurring in the skin of the individual species.

As stated above, parallel bioassay was insufficient to distinguish between naturally occurring caerulein-like polypeptides. A similar failure of bioassay could be observed also in the distinction from each other or from caerulein of a number of synthetic caerulein-like polypeptides (Anastasi, Bernardi, Bertaccini, Bosisio, De Castiglione, Erspamer, Goffredo \& Impicciatore, 1968).

However, the parallel use of appropriate test preparations will always permit, even in the case of crude skin extracts containing a mixture of active peptides, not only the qualitative demonstration of caerulein-like peptides, but also their quantitative estimation as caerulein. Among the most suitable preparations are the guineapig gall bladder, the dog pancreas and the rat stomach preparation. They are 
extremely sensitive to caerulein and, when taken together, highly specific for the polypeptide.

From results obtained in Phyllomedusa burmeisteri it would appear that caeruleinlike polypeptides are preferably located in the glandular formations of the skin. This would suggest that phyllocaerulein too, like other active peptides and biogenic amines, is destined for external secretion.

It will be seen in a forthcoming paper that authentic caerulein or caerulein-like polypeptides are present also in skin extracts of Leptodoctylus pentadactylus labyrinthicus and related leptodactylid frogs from South America as well as in Xenopus laevis from South Africa.

The reason for the occurrence in the skin of some amphibian species, found in South America, Africa and Australia, of peptides strictly similar to the duodenal hormone cholecystokinin-pancreozymin and as such furnished with a formidable activity on motility and secretions of the gut, continues to remain obscure.

It is interesting to note that in Phyllomedusa skin tryptophane-containing peptides are not represented merely by caerulein-like peptides. Several other peptides containing tryptophane in their molecule are present, often in considerable amounts. It is reasonable to suppose that their study will be rewarding, in spite of their apparent inactivity on our present biological preparations. Curiously enough, the attendant tryptophane-containing peptides were particularly abundant in the Phyllomedusa species which lacked caerulein-like peptides in their skin, such as Phyllomedusa rohdei and Phyllomedusa hypochondrialis.

This work was supported by grants from the Consiglio Nationale delle Richerche, Rome.

\section{REFERENCES}

ANASTASI, A. (1969). The enzymatic degradation of phyllocaerulein and analogs. Experientia, 25, 8-9.

ANASTASI, A., Bertaccini, G. \& ERSPAMER, V. (1966). Pharmacological data on phyllokinin (bradykinyl-isoleucyl-tyrosine $\dot{O}$-sulphate) and bradykinyl-isoleucyl-tyrosine. Br.J. Pharmac. Chemother., 27, 479-485.

ANASTASI, A., ERSPAMER, V. \& ENDEAN, R. (1968). Isolation and amino acid sequence of caerulein, the active decapeptide of the skin of Hyla caerulea. Arch. Biochem. Biophys., 125, 57-68.

anastasi, A., Bernardi, L., Bertaccini, G., Bosisio, G., De Castiglione, R., Erspamer, V., GofFREDO, O. \& IMPICCIATORE, M. (1968). Synthetic peptides related to caerulein. Note 1. Experientia, 24, 771-773.

Bertaccini, G., Cei, J. M. \& ErSPaMer, V. (1965). Occurrence of physalaemin in extracts of the skin of Physalaemus fuscumaculatus and its pharmacological actions on extravascular smooth muscle. Br. J. Pharmac. Chemother., 25, 363-369.

Bertaccini, G., De Caro, G., Endean, R., Erspamer, V. \& Impicciatore, M. (1968a). The action of caerulein on the systemic arterial blood pressure of some experimental animals. Br.J. Pharmac. Chemother., 33, 59-71.

Bertaccini, G., De Caro, G., Endean, R., Erspamer, V. \& Impicciatore, M. (1968b). The actions of caerulein on the smooth muscles of the gastrointestinal tract and the gall bladder. $B r . J$. Pharmac., 34, 291-310.

Bertaccini, G., Endean, R., Erspamer, V. \& Impicciatore, M. (1968). The actions of caerulein on gastric secretion of the dog and the rat. Br.J. Pharmac., 34, 311-329.

Bertaccini, G., De Caro, G., Endean, R., Erspamer, V., \& Impicciatore, M. (1969). The action of caerulein on pancreatic secretion of the dog and biliary secretion of the dog and the rat. $B r . J$. Pharmac., 37, 185-197.

De Caro, G., Endean, R., Erspamer, V. \& Roseghini, M. (1968). Occurrence of caerulein in extracts of the skin of Hyla caerulea and other Australian hylids. Br. J. Pharmac. Chemother., $33,48-58$.

ERSPaMer, V. \& Falconieri Erspamer, G. (1962). Pharmacological actions of eledoisin on extravascular smooth muscle. Br. J. Pharmac. Chemother., 19, 337-354.

ERSPAMER, V., BertaccinI, G. \& Cei, J. M. (1962). Occurrence of bradykinin-like substances in amphibian skin. Experientia, 18, 363-364. 